\title{
PENGARUH MEDIA TANAM DAN INTENSITAS NAUNGAN TERHADAP PERTUMBUHAN BIBIT API-API (Avicennia alba)
}

\author{
The Influence of Planting Media and Shade Level on the Seedling Growth \\ of Api-Api Seedling (Avicennia alba)
}

Cecep Kusmana $^{1^{*}}$ dan Fadlilatul Hasanah ${ }^{2}$

(Diterima 31 Desember 2020/Disetujui 10 Mei 2021)

\begin{abstract}
Mangrove forests are ecosystems located in tidal areas in coastal areas, beaches, and small islands. The area of mangrove forests is decreasing due to the conversion of mangrove forests into fishponds, plantations, and timber exploitation. Mangrove ecosystem rehabilitation activities need to be carried out through planting. Avicennia alba is a pioneer mangrove species that grows in mangrove swamp habitats on sheltered coastal locations, as well as in the saltier parts of the coastline. The objectives of this research is to analyze the effect of planting media and shade intensity on the seedling growth of Avicennia alba. The study used a two-factor experimental design in a complete randomized design. The first factor is planting media and the second one in shade intensity. The results showed that the shading intensity most influenced the growth of Avicennia alba seedlings. The variables affected include height, diameter, number of leaves, total wet weight, and total dry weight. The treatment combination that gave the best results was $\mathrm{A} 2 \mathrm{NO}$, that means the planting medium in the form of a mixture of mud, sand and compost and without shade $(0 \%$ shade).
\end{abstract}

Keywords: Avicennia alba, growth, photosynthesis, planting media, shade intensity

\begin{abstract}
ABSTRAK
Hutan mangrove merupakan ekosistem yang berada di daerah pasang surut di wilayah pesisir, pantai, dan pulaupulau kecil. Luas hutan mangrove semakin berkurang akibat konversi hutan mangrove menjadi tambak, perkebunan, dan eksploitasi kayu. Kegiatan rehabilitasi ekosistem mangrove perlu dilakukan melalui penanaman. Avicennia alba merupakan jenis mangrove pionir yang tumbuh pada habitat rawa mangrove di lokasi pantai yang terlindung, juga di bagian yang lebih asin di sepanjang garis pantai. Tujuan penelitian ini adalah menganalisis pengaruh media tanam dan intensitas naungan terhadap pertumbuhan bibit Api-Api (Avicennia alba). Penelitian ini menggunakan rancangan percobaan dua faktor dalam rancangan acak lengkap (RAL). Faktor pertama yaitu media tanam dan faktor kedua adalah intensitas naungan. Hasil penelitian menunjukkan bahwa faktor intensitas naungan paling mempengaruhi pertumbuhan bibit Avicennia alba. Variabel yang terpengaruhi antara lain tinggi, diameter, jumlah daun, berat basah total (BBT), dan berat kering total (BKT). Kombinasi perlakuan yang memberikan hasil terbaik adalah A2N0, yaitu media tanam berupa campuran antara lumpur, pasir, dan kompos serta tanpa diberi naungan (naungan 0\%).
\end{abstract}

Kata kunci: Avicennia alba, fotosintesis, intensitas naungan, media tanam, pertumbuhan

\footnotetext{
${ }^{1}$ Departemen Silvikultur, Fakultas Kehutanan dan Lingkungan, IPB University

* Penulis korespondensi:

e-mail: ckmangrove@gmail.com

${ }^{2}$ Mahasiswa Sarjana Departemen Silvikultur, Fakultas Kehutanan dan Lingkungan, IPB University
} 


\section{PENDAHULUAN}

Hutan mangrove merupakan ekosistem yang berada di daerah pasang surut di wilayah pesisir, pantai, dan pulaupulau kecil serta merupakan sumber daya alam yang sangat potensial (Halidah 2014). Perkiraan luas hutan mangrove di dunia sangat beragam. Beberapa peneliti menyebutkan luas hutan mangrove di seluruh dunia adalah 15 juta hektar (Ogino dan Chihara 1988), sedangkan Groombridge (1992) menyebutkan 19.9 juta hektar. Luas hutan mangrove di kawasan Asia diperkirakan sekitar 32\% sampai $41.5 \%$ luas hutan mangrove dunia (Noor et al. 2006). Indonesia diperkirakan memiliki hutan mangrove seluas 3.5 juta hektar melebihi Brazil (1.3 juta ha), Nigeria (1.1 juta ha), dan Australia (0.97 juta ha) (Spalding et al. 1997). Hutan mangrove memiliki peran penting sebagai habitat biota perairan, penahan abrasi dan tsunami, penyerap limbah, pencegah intrusi air laut, serta sebagai penyedia kayu dan bahan baku obat-obatan.

Luas hutan mangrove semakin berkurang akibat konversi hutan mangrove menjadi tambak, perkebunan, dan eksploitasi kayu sebagai kayu bakar, bahan bangunan, pembuatan arang, serta alat untuk menangkap ikan (Rizki dan Novi 2017). Pemanfaatan hutan mangrove pada dasarnya bertujuan meningkatkan perekonomian masyarakat di daerah pesisir. Akan tetapi, kegiatan tersebut dilakukan secara berlebihan tanpa memikirkan kondisi ekologi hutan mangrove sehingga berdampak pada kerusakan ekosistem mangrove. Indonesia dalam kurun waktu 2000-2014 tercatat sebagai negara penyumbang kehilangan hutan mangrove terluas di dunia, yaitu 4364 $\mathrm{km}^{2}$ atau sekitar $311 \mathrm{~km}^{2}$ per tahunnya (Hamilton dan Casey 2016). Luas hutan mangrove yang semakin berkurang menyebabkan kehilangan habitat bagi biota air dan menurunnya luas daratan di pesisir.

Kegiatan rehabilitasi perlu dilakukan untuk melestarikan ekosistem mangrove. Upaya yang dilakukan adalah melalui penanaman. Keberhasilan penanaman didukung oleh ketersediaan bibit dari berbagai jenis mangrove. Pembibitan mangrove sudah banyak dilakukan, namun terdapat kendala seperti keadaan lingkungan lokasi pembibitan, pengaruh pasang surut air laut, dan keadaan ombak di pantai yang tidak menentu (Rizki dan Novi 2017). Pemilihan bibit yang sehat juga berpengaruh terhadap keberhasilan pembibitan. Bibit yang baik dapat diperoleh dengan melakukan pemeliharaan secara rutin seperti penyulaman, pembersihan dari gulma, pengendalian hama dan penyakit serta mempertahankan tegakan bibit (Wibisono et al. 2006).

Avicennia merupakan marga yang memiliki kemampuan toleransi terhadap kisaran salinitas yang luas dibandingkan dengan marga lainnya sehingga cocok digunakan dalam kegiatan rehabilitasi ekosistem mangrove. Avicennia mendominasi areal yang selalu digenangi walaupun pada saat pasang rendah. Avicennia alba merupakan jenis pionir pada habitat rawa mangrove di lokasi pantai yang terlindung, juga di bagian yang lebih asin di sepanjang garis pantai (Noor et al. 2006). Avicennia alba (Api-Api) berperan penting dalam pengikatan sedimen dan mempercepat proses pembentukan daratan. Pembibitan Avicennia alba di lokasi sekitar pohon induk maupun di pesisir pantai menyebabkan bibit terkena ombak dan pasang surut air laut sehingga lumpur tempat tumbuhnya semakin terkikis. Akibatnya sumber nutrisi yang terdapat di dalam lumpur tersebut dapat ikut terkikis. Pembibitan di luar habitat mangrove dapat dilakukan untuk mengatasi hal tersebut. Berdasarkan hal ini, perlu dilakukan penelitian untuk mengetahui komposisi media tanam dan naungan yang baik terhadap pertumbuhan bibit Avicennia alba (Api-Api).

\section{METODE PENELITIAN}

\section{Waktu dan Tempat Penelitian}

Penelitian dilakukan di Rumah Kaca Laboratorium Ekologi Hutan Departemen Silvikultur, Fakultas Kehutanan dan Lingkungan, Institut Pertanian Bogor, pada bulan Januari 2020 sampai dengan bulan April 2020.

\section{Alat dan Bahan}

Alat yang digunakan dalam penelitian ini antara lain selang, sekop, timbangan, penggaris, kaliper, oven, tabel tally sheet, alat tulis, kamera, Microsoft Excel, dan Software SAS 9.1. Adapun bahan yang digunakan meliputi kolam terpal, ajir, bambu, polybag berukuran $20 \mathrm{~cm}$ x 20 $\mathrm{cm}$, paranet intensitas $50 \%$ dan $70 \%$, bibit Avicennia alba, air, dan media (lumpur mangrove, pasir, dan kompos).

\section{Prosedur Penelitian}

\section{Persiapan Kolam}

Kolam berfungsi untuk meletakkan bibit mangrove yang telah diberi perlakuan media. Jumlah kolam yang digunakan adalah tiga buah untuk perlakuan naungan yang berbeda yaitu naungan 0\%, 50\%, dan 70\%. Masing-masing kolam diberi tiang yang berfungsi sebagai tempat meletakkan paranet dengan intensitas yang berbeda.

\section{Pemilihan Bibit}

Bibit Api-Api (Avicennia alba) yang dipilih adalah bibit yang berumur 3 bulan dan memiliki kenampakan fenotipe yang sehat serta memiliki tinggi dan diameter yang seragam. Bibit yang telah dipilih sejumlah 36 bibit.

\section{Persiapan Bibit dan Media}

Bibit yang telah sampai di rumah kaca selanjutnya dipindahkan ke polybag yang berukuran lebih besar $(20 \mathrm{~cm}$ x $20 \mathrm{~cm}$ ). Media yang digunakan pada polybag baru merupakan media tanam berupa campuran tanah, kompos dan pasir dengan perbandingan yang berbeda-beda yaitu 1 $\mathrm{kg}$ lumpur (A0), $0.7 \mathrm{~kg}$ lumpur dan $0.3 \mathrm{~kg}$ kompos (A1), serta $0.4 \mathrm{~kg}$ lumpur; $0.3 \mathrm{~kg}$ pasir; $0.3 \mathrm{~kg}$ kompos (A2). Bibit kemudian disusun di dalam kolam dan digenangi selama masa aklimatisasi setelah pemindahan ke polybag baru. Hal ini dimaksudkan agar bibit bisa melakukan adaptasi terlebih dahulu dengan lingkungan rumah kaca. 


\section{Pemasangan Paranet}

Pemasangan paranet dilakukan setelah masa aklimatisasi selesai (dua minggu setelah pemindahan bibit ke dalam polybag). Pemasangan paranet dilakukan dengan mengaitkan paranet pada tiang penyangga yang telah dibuat sebelumnya.

\section{Pengamatan dan pengukuran}

Pengamatan dan pengukuran Avicennia alba dilakukan untuk mengkaji ada tidaknya perubahan pada kondisi bibit akibat pengaruh perlakuan perbedaan media tanam dan intensitas naungan. Kegiatan ini dilakukan secara rutin, yakni satu kali pengamatan setiap minggu selama tiga bulan. Parameter yang diamati dalam penelitian ini adalah tinggi, diameter, jumlah daun, berat basah total (BBT), berat kering total (BKT), dan nisbah pucuk akar (NPA).

\section{a. Tinggi bibit}

Pengukuran tinggi dilakukan dengan menggunakan penggaris dari pangkal batang yang telah ditandai $3 \mathrm{~cm}$ di atas permukaan media hingga titik tumbuh pucuk apikal.

\section{b. Diameter bibit}

Pengukuran diameter dilakukan dengan menggunakan kaliper digital dengan ketelitian $10^{-2}$ pada pangkal batang yang telah ditandai $3 \mathrm{~cm}$ di atas permukaan media.

\section{c. Jumlah daun}

Jumlah daun dihitung bersamaan dengan pengukuran diameter dan tinggi bibit. Jumlah daun yang digunakan pada pengolahan data adalah jumlah daun akhir dikurangi jumlah daun awal.

\section{d. Berat basah total (BBT)}

Pengukuran berat basah total dilakukan pada akhir penelitian (pada minggu ke-12). Tanaman dipisahkan antara bagian pucuk (daun dan batang) dengan bagian akar. Bagian pucuk dan bagian akar masing-masing ditimbang dengan menggunakan timbangan digital. Berat basah total diperoleh dari penjumlahan antara berat basah pucuk dan berat basah akar.

\section{e. Berat kering total (BKT)}

Pengukuran berat kering total dilakukan pada akhir penelitian (pada minggu ke-12). Bibit dikeringkan dalam oven dengan suhu $80^{\circ} \mathrm{C}$ selama 24 jam, kemudian bagian pucuk dan akar yang telah dioven ditimbang masing-masing. Berat kering total diperoleh dengan menjumlahkan berat kering pucuk dan berat kering akar.

\section{f. Nisbah pucuk akar (NPA)}

Nisbah pucuk akar merupakan perbandingan antara berat kering bagian pucuk dengan berat kering bagian akar. Berat kering bagian pucuk terdiri dari batang, cabang, dan daun yang ditimbang setelah dioven. Bagian akar diperoleh dengan menimbang bagian akar bibit setelah dioven. Pengukurannya dilakukan bersamaan dengan pengukuran berat kering total.

$$
\mathrm{NPA}=\frac{\text { Berat Kering Pucuk }(\mathrm{g})}{\text { Berat Kering Akar }(\mathrm{g})}
$$

\section{Pengolahan dan analisis data}

Rancangan percobaan yang digunakan dalam penelitian ini adalah rancangan percobaan faktorial rancangan acak lengkap (RAL) $3 \times 3 \times 4$. Penelitian ini menggunakan 2 fakor perlakuan, yaitu faktor media tanam (A) dan faktor naungan $(\mathrm{N})$ dengan masing-masing faktor terdapat tiga taraf. Taraf pada faktor media tanam, yaitu 1 $\mathrm{kg}$ tanah lumpur mangrove (A0); $0.7 \mathrm{~kg}$ tanah lumpur mangrove dan $0.3 \mathrm{~kg}$ kompos (A1); serta $0.4 \mathrm{~kg}$ tanah lumpur mangrove, $0.3 \mathrm{~kg}$ pasir, dan $0.3 \mathrm{~kg}$ kompos (A2). Taraf pada faktor naungan, yaitu naungan $0 \%$ atau tanpa naungan (N0), naungan 50\% (N1), dan naungan $70 \%(\mathrm{~N} 2)$, sehingga terdapat sembilan kombinasi perlakuan sebagai berikut:

1. A0N0 : media tanam tanah lumpur mangrove dengan naungan $0 \%$

2. A0N1 : media tanam tanah lumpur mangrove dengan naungan $50 \%$

3. A0N2 : media tanam tanah lumpur mangrove dengan naungan $70 \%$

4. A1N0 :media tanam tanah lumpur mangrove dan kompos dengan naungan $0 \%$

5. A1N1 :media tanam tanah lumpur mangrove dan kompos dengan naungan 50\%

6. A1N2 : media tanam tanah lumpur mangrove dan kompos dengan naungan $70 \%$

7. A2N0 : media tanam tanah lumpur mangrove, pasir, dan kompos dengan naungan $0 \%$

8. A2N1 : media tanam tanah lumpur mangrove, pasir, dan kompos dengan naungan $50 \%$

9. A2N2 : media tanam tanah lumpur mangrove, pasir, dan kompos dengan naungan $70 \%$

Setiap kombinasi perlakuan terdiri dari 4 ulangan bibit tanaman. Total terdapat 12 kombinasi perlakuan dengan 36 unit bibit tanaman. Model persamaan linier dari percobaan faktorial dalam Rancangan Acak Lengkap (RAL) adalah sebagai berikut (Mattjik dan Sumertajaya 2006):

$$
Y \mathrm{ijk}=\mu+\alpha \mathrm{i}+\beta \mathrm{j}+(\alpha \beta) \mathrm{ij}+\varepsilon \mathrm{ijk}
$$

Keterangan :

Yijk : respon pertumbuhan terbaik dari bibit ke-k yang dipengaruhi media tanam ke-i dan intensitas naungan ke-j

$\mu \quad$ : rataan umum

$\alpha i \quad$ : pengaruh perlakuan dari media tanam ke-i

$\beta \quad$ : pengaruh perlakuan dari intensitas naungan ke-j

$(\alpha \beta) i$ : pengaruh interaksi dari media tanam ke-i pada intensitas naungan ke-j

eij : pengaruh acak percobaan dari bibit ke-k yang dipengaruhi media tanam ke-i dan intensitas naungan ke-j

i $: 1,2,3$

j $: 1,2,3$

$\mathrm{k} \quad: 1,2,3,4$

Analisis data dilakukan dengan sidik ragam (ANOVA). Apabila terdapat pengaruh yang nyata pada variabel percobaan, maka dilanjutkan dengan uji Duncan. Pengolahan data menggunakan software Microsoft Office Excel 2016 dan SAS 9.1. 


\section{HASIL DAN PEMBAHASAN}

\section{Rekapitulasi Hasil Sidik Ragam}

Variabel yang diamati pada penelitian ini antara lain pertumbuhan tinggi, pertumbuhan diameter, jumlah daun, berat basah total (BBT), berat kering total (BKT), dan nisbah pucuk akar (NPA). Rekapitulasi hasil sidik ragam terhadap seluruh variabel pengamatan dapat dilihat pada Tabel 1.

Berdasarkan Tabel 1 dapat diketahui bahwa pertumbuhan bibit Avicennia alba dipengaruhi oleh media tanam dan intensitas naungan. Variabel berat kering total (BKT) pada perlakuan media tanam (A) memberikan hasil yang berbeda nyata pada selang kepercayaan 5\%. Semua variabel pada perlakuan intensitas naungan (N) memberikan hasil yang berbeda nyata pada selang kepercayaan 5\%, kecuali nisbah pucuk akar (NPA). Interaksi antara media tanam dengan intensitas naungan tidak berbeda nyata pada selang kepercayaan $5 \%$. Intensitas naungan merupakan faktor yang paling berpengaruh terhadap pertumbuhan bibit Avicennia alba.

\section{Pertumbuhan Tinggi}

Berdasarkan tabel hasil sidik ragam (Tabel 1), intensitas naungan memberikan hasil berbeda nyata pada selang kepercayaan 5\% sehingga dilakukan uji lanjut menggunakan uji Duncan.

Tabel 2 menunjukkan bahwa intensitas naungan memberikan hasil berbeda nyata terhadap pertumbuhan tinggi bibit. Berdasarkan hasil uji lanjut Duncan (Tabel 2), rata-rata pertumbuhan bibit tertinggi terdapat pada perlakuan N0. Perlakuan N0 tidak berbeda nyata dengan $\mathrm{N} 1$, namun berbeda nyata dengan perlakuan N2.

Tabel 1 Hasil sidik ragam variabel pertumbuhan bibit Avicennia alba

\begin{tabular}{lccc}
\hline & \multicolumn{3}{c}{ F Hitung } \\
\cline { 2 - 4 } Variabel & $\begin{array}{c}\text { Media } \\
\text { Tanam } \\
\text { (A) }\end{array}$ & $\begin{array}{c}\text { Intensitas } \\
\text { Naungan } \\
(\mathrm{N})\end{array}$ & $\begin{array}{c}\text { Interaksi } \\
\text { (AN) }\end{array}$ \\
\hline Tinggi & tn & $*$ & tn \\
Diameter & tn & $*$ & tn \\
Jumlah & tn & $*$ & tn \\
daun & tn & $*$ & tn \\
BBT & $*$ & $*$ & tn \\
BKT & tn & tn & tn \\
NPA &
\end{tabular}

$\overline{\text { Keterangan: * = berpengaruh nyata pada selang kepercayaan }}$ $95 \%$; $\mathrm{tn}=$ tidak berpengaruh nyata

Tabel 2 Hasil uji Duncan pengaruh intensitas naungan terhadap pertumbuhan tinggi bibit Avicennia alba

\begin{tabular}{cc}
\hline $\begin{array}{c}\text { Intensitas } \\
\text { Naungan }\end{array}$ & $\begin{array}{c}\text { Rata-rata pertumbuhan } \\
\text { tinggi }(\mathrm{cm})\end{array}$ \\
\hline N0 & $14.258^{\mathrm{a}}$ \\
$\mathrm{N} 1$ & $8.200^{\mathrm{a}}$ \\
$\mathrm{N} 2$ & $3.892^{\mathrm{b}}$ \\
\hline
\end{tabular}

$\overline{\text { Keterangan: angka yang diikuti oleh huruf yang sama berarti }}$ tidak berbeda nyata pada selang kepercayaan $5 \%$
Pertumbuhan tinggi bibit optimal terjadi pada perlakuan tanpa naungan. Intensitas cahaya yang tinggi membuat tanaman mengurangi respirasi untuk mencegah kehilangan air sehingga fokus pertumbuhan terjadi pada bagian batang. Pertambahan tinggi tanaman terjadi akibat pembelahan meristem ujung yang menghasilkan sel-sel baru di ujung akar atau batang (Gardner et al. 1991). Pembelahan sel terjadi berkat adanya bantuan dari cahaya matahari.

\section{Pertumbuhan Diameter}

Berdasarkan hasil analisis sidik ragam pada Tabel 1, intensitas naungan memberikan hasil beda nyata terhadap pertumbuhan diameter bibit pada selang kepercayaan 5\% sehingga dilakukan uji lanjut dengan uji Duncan.

Tabel 3 menunjukkan bahwa intensitas naungan memberikan hasil berbeda nyata terhadap pertumbuhan diameter bibit. Berdasarkan hasil uji lanjut Duncan (Tabel 3), rata-rata diameter bibit tertinggi terdapat pada perlakuan N0. Perlakuan N0, N1, dan N2 masing-masing memberikan hasil beda nyata. Tanaman pada intensitas cahaya yang cukup memacu pertumbuhan diameternya (Marjaenah 2001).

Intensitas cahaya penuh merupakan kondisi yang paling baik untuk mendukung pertumbuhan diameter batang bibit Avicennia alba. Daniel et al. (1992) menyatakan bahwa pertumbuhan diameter tanaman dipengaruhi spektrum cahaya matahari yang merangsang aktivitas hormon dalam proses pembentukan sel meristematik ke arah diameter batang. Pemberian naungan pada bibit Avicennia alba menghambat cahaya matahari.

\section{Pertumbuhan Jumlah Daun}

Berdasarkan hasil analisis sidik ragam pada Tabel 1, intensitas naungan memberikan hasil beda nyata terhadap jumlah daun bibit pada selang kepercayaan 5\% sehingga dilakukan uji lanjut dengan uji Duncan.

Tabel 4 menunjukkan bahwa rata-rata pertumbuhan jumlah daun tertinggi terdapat pada perlakuan N1. Hal ini sesuai dengan hasil penelitian Widiastoety et al. (2000)

Tabel 3 Hasil uji Duncan pengaruh intensitas naungan terhadap pertumbuhan diameter bibit Avicennia alba

\begin{tabular}{cc}
\hline $\begin{array}{c}\text { Intensitas } \\
\text { Naungan }\end{array}$ & Rata-rata pertumbuhan diameter $(\mathrm{mm})$ \\
\hline N0 & $2.8250^{\mathrm{a}}$ \\
N1 & $1.1750^{\mathrm{b}}$ \\
N2 & $0.9250^{\mathrm{c}}$
\end{tabular}

Keterangan: angka yang diikuti oleh huruf yang sama berarti tidak berbeda nyata pada selang kepercayaan $5 \%$

Tabel 4 Hasil uji Duncan pengaruh intensitas naungan terhadap jumlah daun bibit Avicennia alba

\begin{tabular}{cc}
$\begin{array}{c}\text { Intensitas } \\
\text { Naungan }\end{array}$ & Rata-rata pertumbuhan jumlah daun \\
\hline N1 & $11.083^{\mathrm{a}}$ \\
N0 & $9.333^{\mathrm{a}}$ \\
$\mathrm{N} 2$ & $1.083^{\mathrm{b}}$ \\
\hline
\end{tabular}

Keterangan: angka yang diikuti oleh huruf yang sama berarti tidak berbeda nyata pada selang kepercayaan $5 \%$ 
yang membuktikan bahwa tanaman pada intensitas cahaya $55 \%$ memberikan produksi bunga dan lebar daun tertinggi serta pembentukan tunas terbaik. Tanaman di tempat ternaung menumbuhkan lebih banyak daun untuk meningkatkan jumlah stomata sehingga dapat menyerap cahaya lebih banyak untuk proses fotosintesis.

Perlakuan N1 tidak berbeda nyata dengan perlakuan N0, namun berbeda nyata dengan perlakuan N2. Hal ini berarti bibit Avicennia alba dapat memproduksi daun yang cukup meskipun tidak berada di tempat yang ternaungi. Total luas daun aktif dalam tanaman yang dapat melakukan fotosintesis akan berpengaruh terhadap produk fotosintesis yang akan dihasilkan (Irawan dan Hidayah 2017). Semakin sedikit jumlah daun pada tanaman maka semakin sedikit produk fotosintesis yang dihasilkan.

\section{Berat Basah Total}

Berdasarkan hasil analisis sidik ragam (Tabel 1), intensitas naungan memberikan hasil beda nyata terhadap berat basah total pada selang kepercayaan 5\% sehingga dilakukan uji lanjut dengan uji Duncan.

Tabel 5 menunjukkan intensitas naungan memberikan hasil berbeda nyata terhadap berat basah total. Berdasarkan hasil uji lanjut Duncan (Tabel 5), rata-rata berat basah total tertinggi terdapat pada perlakuan N0 dengan diikuti dengan perlakuan N1 dan N2. Hasil uji lanjut Duncan juga menunjukkan bahwa perlakuan N0, N1, dan N2 masingmasing memberikan hasil beda nyata.

Tabel 5 Hasil uji Duncan pengaruh intensitas naungan terhadap berat basah total bibit Avicennia alba

\begin{tabular}{cc}
\hline $\begin{array}{c}\text { Intensitas } \\
\text { Naungan }\end{array}$ & $\begin{array}{c}\text { Rata-rata berat basah } \\
\text { total }(\mathrm{g})\end{array}$ \\
\hline N0 & $32.704^{\mathrm{a}}$ \\
$\mathrm{N} 1$ & $24.525^{\mathrm{b}}$ \\
$\mathrm{N} 2$ & $10.796^{\mathrm{c}}$
\end{tabular}

$\overline{\text { Keterangan: angka yang diikuti oleh huruf yang sama berarti }}$ tidak berbeda nyata pada selang kepercayaan $5 \%$

Tabel 6 Hasil uji Duncan pengaruh media tanam terhadap berat kering total bibit Avicennia alba

\begin{tabular}{cc}
\hline Media Tanam & $\begin{array}{c}\text { Rata-rata berat kering } \\
\text { total }(\mathrm{g})\end{array}$ \\
\hline A1 & $7.2542^{\mathrm{a}}$ \\
A2 & $6.9292^{\mathrm{a}}$ \\
A0 & $4.8958^{\mathrm{b}}$
\end{tabular}

$\overline{\text { Keterangan: angka yang diikuti oleh huruf yang sama berarti }}$ tidak berbeda nyata pada selang kepercayaan 5\%

Tabel 7 Hasil uji Duncan pengaruh intensitas naungan terhadap berat kering total bibit Avicennia alba

\begin{tabular}{cc}
\hline $\begin{array}{c}\text { Intensitas } \\
\text { Naungan }\end{array}$ & $\begin{array}{c}\text { Rata-rata berat kering } \\
\text { total }(\mathrm{g})\end{array}$ \\
\hline $\mathrm{N} 0$ & $9.7375^{\mathrm{a}}$ \\
$\mathrm{N} 1$ & $6.3000^{\mathrm{b}}$ \\
$\mathrm{N} 2$ & $3.0417^{\mathrm{c}}$ \\
\hline
\end{tabular}

Keterangan: angka yang diikuti oleh huruf yang sama berarti tidak berbeda nyata pada selang kepercayaan $5 \%$
Gambar 1 menunjukkan kombinasi antara media tanam dan intensitas naungan. Kombinasi perlakuan pada taraf A2N0 memberikan hasil berat basah total terbesar. Berat basah merupakan total berat tanaman yang menunjukkan hasil aktivitas metabolik tanaman (Sallisburry dan Ross 1995).

Aktivitas metabolik yang baik menyebabkan pertumbuhan tanaman yang baik. Bibit Avicennia alba pada naungan $0 \%$ memiliki pertumbuhan yang paling baik. Energi yang dihasilkan dari proses metabolisme cukup untuk melakukan fotosintesis dan menghasilkan karbohidrat yang menambah massa bibit.

\section{Berat Kering Total}

Berdasarkan hasil analisis sidik ragam (Tabel 1), media tanam dan intensitas naungan memberikan hasil beda nyata terhadap berat kering total pada selang kepercayaan 5\% sehingga dilakukan uji lanjut dengan uji Duncan.

Tabel 6 menunjukkan media tanam memberikan hasil berbeda nyata terhadap jumlah daun bibit. Berdasarkan hasil uji lanjut Duncan (Tabel 6), rata-rata berat kering total tertinggi terdapat pada perlakuan A1 diikuti dengan perlakuan A2 dan A0. Hasil uji lanjut Duncan juga menunjukkan bahwa perlakuan yang memberikan hasil beda nyata adalah perlakuan A0.

Tabel 7 menunjukkan intensitas naungan memberikan hasil berbeda nyata terhadap jumlah daun bibit. Berdasarkan hasil uji lanjut Duncan (Tabel 7), rata-rata berat kering total tertinggi terdapat pada perlakuan N0,

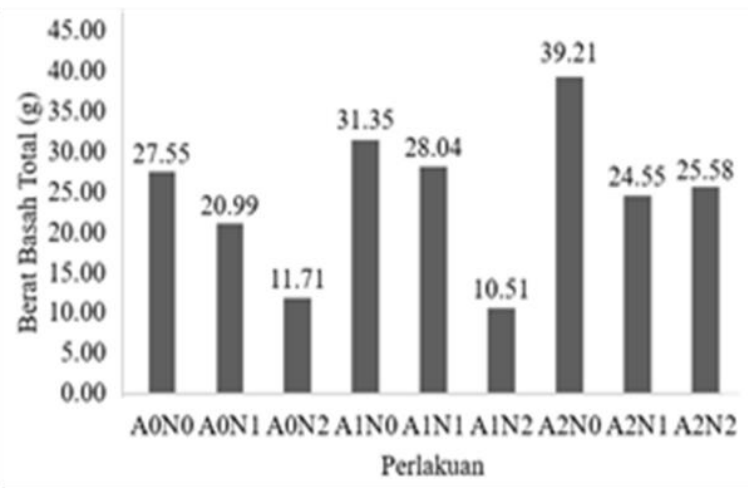

Gambar 1 Berat basah total bibit Avicennia alba umur 6 bulan pada berbagai kombinasi antara media tanam $(\mathrm{A})$ dan intensitas naungan $(\mathrm{N})$

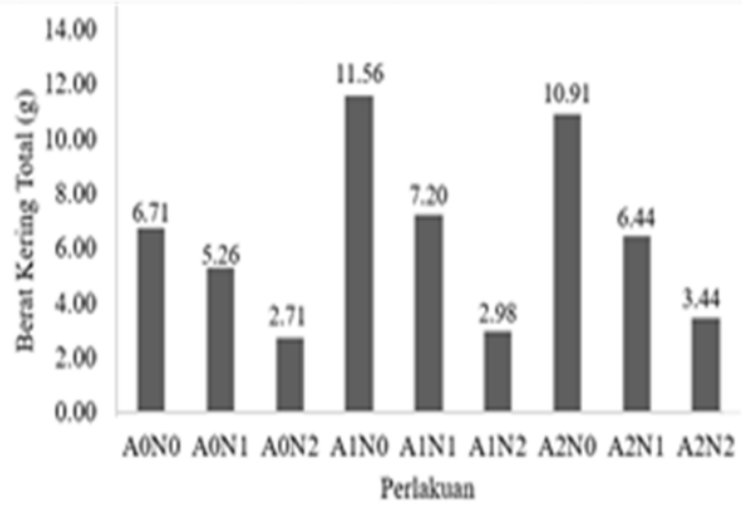

Gambar 2 Berat kering total bibit Avicennia alba umur 6 bulan pada berbagai kombinasi antara media tanam $(\mathrm{A})$ dan intensitas naungan $(\mathrm{N})$ 
diikuti dengan perlakuan N1 dan N2. Hasil uji lanjut Duncan juga menunjukkan bahwa perlakuan N0, N1, dan $\mathrm{N} 2$ masing-masing memberikan hasil beda nyata.

Kombinasi perlakuan pada taraf A1N0 memberikan hasil berat kering total terbesar (Gambar 2). Berat kering merupakan hasil dari penimbunan hasil bersih asimilasi $\mathrm{CO}_{2}$ (Larcher 1975). Nilai berat kering total (BKT) menunjukkan nilai biomassa dan berbanding lurus dengan nilai biomassa tersebut. Selama masa hidupnya tanaman membentuk biomassa yang mengakibatkan pertambahan berat dan diikuti dengan pertambahan dimensi lain yang dapat dinyatakan secara kuantitatif (Sitompul dan Guritno 1995).

Nilai berat kering total bibit Avicennia alba dipengaruhi oleh media tanam dan intensitas naungan, namun interaksi antara keduanya tidak berpengaruh nyata. Media A1 (lumpur dan kompos) dan A2 (lumpur, pasir, dan kompos) sama-sama memberikan pengaruh terhadap berat kering total.

Bibit Avicennia alba menghasilkan nilai berat kering total tertinggi pada naungan $0 \%$. Intensitas cahaya penuh mendukung fisiologi tanaman secara maksimal. Hal ini sesuai dengan pernyataan Permatasari dan Kusmana (2011) bahwa semakin baik atau semakin efisien proses fisiologis tanaman, maka berat kering tanaman akan semakin besar.

\section{Nisbah Pucuk Akar}

Berdasarkan hasil analisis sidik ragam pada Tabel 1 , media tanam, intensitas naungan, dan interaksi antara keduanya memberikan hasil tidak berbeda nyata pada selang kepercayaan 5\% terhadap nisbah pucuk akar. Nilai nisbah pucuk akar pada setiap kombinasi perlakuan disajikan pada Gambar 3.

Nilai rata-rata nisbah pucuk akar bibit Avicennia alba berkisar antara 1.92-3.88. Ramadani (2008) menyebutkan bahwa suatu bibit dikatakan baik jika nilai nisbah pucuk akar seimbang, yaitu berada pada interval 1-3. Hal ini mengindikasikan bahwa sistem perakaran tanaman mampu menopang pertumbuhan pucuknya sehingga bagian pucuk dan akar tanaman kokoh dan tidak mudah roboh (Wibisono

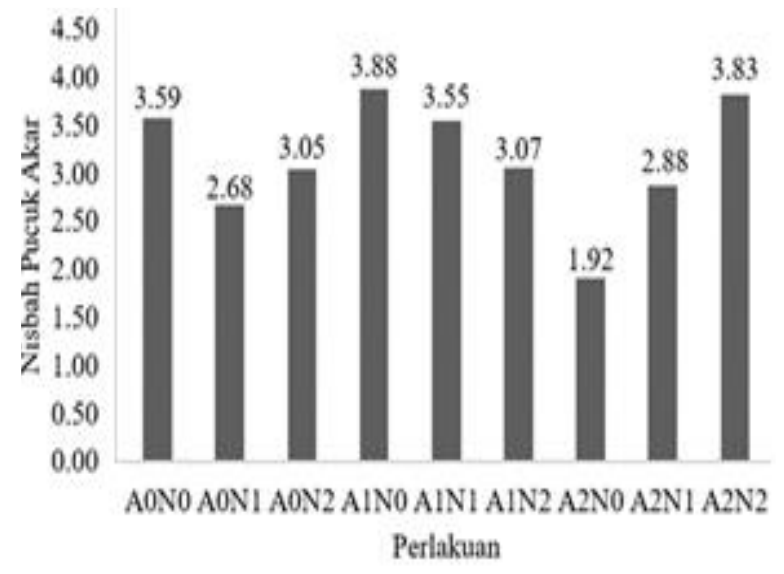

Gambar 3 Nisbah pucuk akar bibit Avicennia alba umur 6 bulan pada berbagai kombinasi antara media tanam (A) dan intensitas naungan $(\mathrm{N})$
2009). Bibit Avicennia alba memiliki nisbah pucuk akar yang baik dan tidak dipengaruhi oleh perlakuan media tanam dan naungan.

Pertumbuhan terbaik bibit Avicennia alba terjadi pada bibit yang berada pada perlakuan naungan $0 \%$ atau tanpa naungan. Bibit yang tidak diberi naungan terlihat lebih segar, sedangkan pada perlakuan ternaungi bibit cenderung lebih pendek dan layu (Gambar 4). Bibit pada naungan 0\% mampu mengoptimalkan pertumbuhan tinggi dan memperbanyak jumlah daun. Banyaknya daun yang tumbuh membuat bibit melakukan fotosintesis secara optimal untuk mendukung pertumbuhan.

Setiap jenis tanaman memiliki respon yang berbedabeda terhadap intensitas cahaya. Keliat (2012) melaporkan bahwa pertumbuhan terbaik bibit Avicennia marina terjadi pada perlakuan naungan $50 \%$ terhadap variabel tinggi, diameter, jumlah daun, dan biomassa. Hasil yang sama dibuktikan oleh penelitian Gultom (2015) terhadap pertumbuhan Sonneratia caseolaris. Kedua jenis mangrove tersebut menunjukkan morfologi yang baik pada tempat yang ternaungi.

Menurut Imran dan Efendi (2016) intensitas, kualitas, dan lama pencahayaan mempengaruhi pertumbuhan maupun kematian mangrove karena mangrove merupakan tumbuhan long day plants yang membutuhkan intensitas cahaya yang tinggi sehingga sesuai untuk hidup di daerah tropis. Ketiadaan sinar akan mempengaruhi kondisi fisiologi tanaman.

Selama 12 minggu pengamatan terdapat gangguan berupa serangan hama ulat grayak dan kutu tempurung

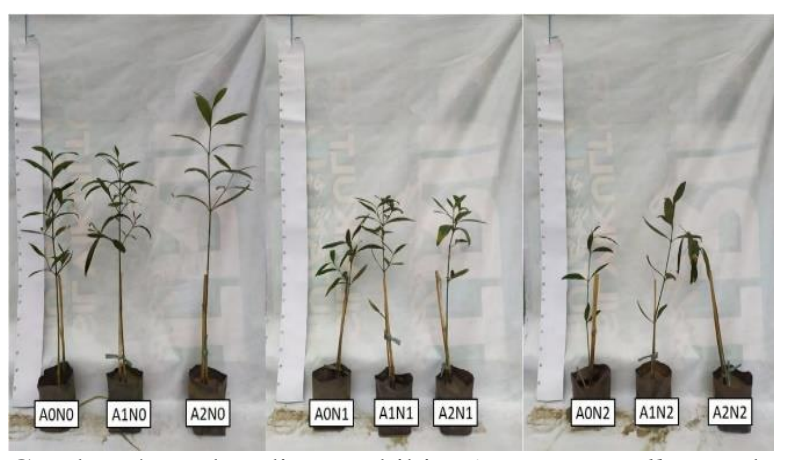

Gambar 4 Perbandingan bibit Avicennia alba pada minggu ke-12 pada berbagai kombinasi perlakuan media $(\mathrm{A})$ dan naungan $(\mathrm{N})$

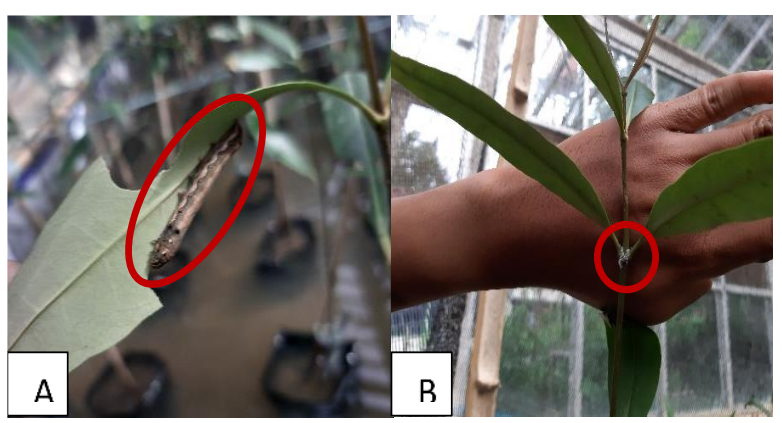

Gambar 5 Gangguan hama yang menyerang bibit Avicennia alba: (A) serangan ulat grayak pada daun dan (B) serangan kutu tempurung pada batang 
pada bibit Avicennia alba. Ulat grayak (Spodoptera sp.) merupakan salah satu hama daun yang memiliki kisaran inang yang luas terutama pada tanaman pertanian dan budidaya (Lestari et al. 2013). Ulat grayak termasuk ke dalam ordo Lepidoptera dengan imago berupa ngengat. Ulat grayak yang dijumpai memakan daun hingga hampir habis, akan tetapi dapat dikendalikan sehingga tidak terlalu berpengaruh terhadap pertumbuhan bibit selama pengamatan berlangsung.

Selain ulat grayak, dijumpai juga kutu tempurung. Kutu tempurung termasuk ke dalam ordo Homoptera famili Coccidae (Rismayani et al. 2013). Menurut Ramadhani (2018), kutu tempurung sering dijumpai menginfestasi bagian daun (terutama di dekat tulang daun) dan batang tanaman. Kutu tempurung yang dijumpai terdapat pada bagian batang bibit Avicennia alba.

\section{SIMPULAN DAN SARAN}

\section{Simpulan}

Respon pertumbuhan bibit Avicennia alba berpengaruh nyata pada perlakuan intensitas naungan. Variabel yang terpengaruh antara lain tinggi, diameter, jumlah daun, berat basah total (BBT), dan berat kering total (BKT). Kombinasi perlakuan yang memberikan hasil terbaik adalah A2N0, yaitu media tanam berupa campuran antara lumpur, pasir, dan kompos serta tanpa diberi naungan (naungan $0 \%$ ).

\section{Saran}

Perlu adanya penelitian mengenai pengaruh media tanam dan intensitas naungan pada jenis-jenis bibit mangrove yang lain.

\section{DAFTAR PUSTAKA}

Daniel TW, Helms JA, Baker FS. 1992. Prinsip-Prinsip Silvikultur. Yogyakarta (ID): Gadjah Mada University Press.

Gardner, Pearce, Mitchell. 1991. Fisiologi Tanaman Budidaya. Jakarta (ID): Universitas Indonesia.

Groombridge B. 1992. Global Biodiversity. Status of the Earth's Living Resources. London (UK): Chapman \& Hall.

Gultom EN. 2015. Pengaruh intensitas cahaya terhadap pertumbuhan dan konten rantai panjang polysoprenoid pada mangrove sejati mayor berjenis sekresi Sonneratia caseolaris (L.) [skripsi]. Medan (ID): Fakultas Pertanian USU.

Halidah. 2014. Avicennia marina (Forssk.) Vierh jenis mangrove yang kaya manfaat. Info Teknis Eboni 11(1):37-44.

Hamilton SE, Casey D. 2016. Creation of high spatiotemporal resolution global database of continuous mangrove forest cover for the 21st century (CGMFC-21). Global Ecology and Biogeography 25(6):729-738.
Imran A, Efendi I. 2016. Inventarisasi mangrove di pesisir Pantai Cemara Lombok Barat. Jurnal Pendidikan Mandala 1(1):105-112.

Irawan A, Hidayah HN. 2017. Pengaruh naungan terhadap pertumbuhan dan mutu bibit cempaka wasian (Magnolia tsiampaca (Miq.) Dandy) di persemaian. Jurnal Wasian 14(1):11-16.

Keliat SR. 2012. Pertumbuhan bibit Avicennia marina pada berbagai intensitas naungan [skripsi]. Medan(ID):Fakultas Pertanian USU.

Larcher W. 1975. Physiological Plant Ecology: Ecophysiology and Stress Physiology of Functional Groups. Third Edition. New York (US): Springer.

Lestari S, Ambarningrum TB, Pratikayo H. 2013. Tabel hidup Spodoptera litura Fabr. dengan pemberian pakan buatan yang berbeda. Jurnal Sain Veteriner 31(2):166-179.

Marjaenah. 2001. Pengaruh perbedaan naungan di persemaian terhadap pertumbuhan dan respon morfologi dua jenis semai meranti. Jurnal Ilmiah Kehutanan Rimba Kalimantan 6(2).

Noor YR, Khazali M, Suryadiputra INN. 2006. Panduan Pengenalan Mangrove di Indonesia. Bogor (ID): PHKA/WI-IP

Ogino, Chihara KM. 1988. Biological System of Mangroves. Laporan Ekspedisi Mangrove Indonesia Timur tahun 1986. Ehime (JP): Ehime University, Japan.

Permatasari I, Kusmana C. 2011. Respon pertumbuhan semai tancang (Bruguiera gymnorrhiza (L.) Lamk.) terhadap tingkat penggenangan di Kawasan Mangrove Jalan Tol Sedyatmo, Jakarta Utara. Jurnal Silvikultur Tropika 2(3):181-186.

Ramadani H. 2008. Formulasi inokulum fungi mikoriza arbuskula (FMA) dan vermikompos dalam meningkatkan kualitas semai jati Muna (Tectona grandis Linn.F.) [skripsi]. Bogor (ID): Fakultas Kehutanan, Institut Pertanian Bogor.

Ramadhani NN. 2018. Keanekaragaman kutu tanaman (Hemiptera: Coccoidea) pada berbagai tanaman di Kebun Raya Bogor [skripsi]. Bogor (ID): Fakultas Pertanian IPB.

Rismayani, Rubiyo, Ibrahim MSD. 2013. Dinamika populasi kutu tempurung (Coccus viridis) dan kutu daun (Aphis gossypii) pada tiga varietas kopi arabika (Coffea arabica). Jurnal Littri 19(4):159166.

Rizki, Novi. 2017. Respon pertumbuhan bibit mangrove Rhizophora apiculata $\mathrm{Bl}$ pada media tanah topsoil. Jurnal Biologi dan Pendidikan Biologi 3(2):41-54.

Salissburry FB, Ross CW. 1995. Fisiologi Tumbuhan Jilid: Perkembangan Tumbuhan dan Fisiologi Lingkungan Edisi Keempat. Bandung (ID): ITB Bandung.

Sitompul SM, Guritno B. 1995. Analisis Pertumbuhan Tanaman. Yogyakarta (ID): Gadjah Mada University Press.

Spalding MD, Blasco F, Field CD. 1996. World Mangrove Atlas. International Society for Mangrove Ecosystems, Okinawa, Japan. Cambridge(UK):UNEP-WCMC.

Wibisono HS. 2009. Pemanfaatan mychorizal helper bacteria (MHBs) dan fungi mikoriza arbuskula 
(FMA) untuk meningkatkan pertumbuhan semai gmelina (Gmelina arborea Roxb.) [skripsi]. Bogor (ID): Fakultas Kehutanan, Institut Pertanian Bogor.

Wibisono ITC, Priyanto EB, Suryadiputra INN. 2006.

Panduan Praktis Rehabilitasi Pantai. Bogor (ID): Wetlands International-Indonesia Programme.
Widiastoety DW. Prasetyo, Salania N. 2000. Pengaruh naungan terhadap produksi tiga kultivar bunga anggrek dendrobium. Jurnal Holtikultura 9:302306. 